\title{
Effect of density on larval development and female productivity of Tisbe holothuriae (Copepoda, Harpacticoida) under laboratory conditions
}

\author{
Qian Zhang ${ }^{1}$ \& G. Uhlig $^{2}$ \\ ${ }^{1}$ Institute of Oceanology, Academia Sinica; 266071, Qingdao, P. R. China \\ ${ }^{2}$ Biologische Anstalt Helgoland; D-27483 Helgoland, Federal Republic of Germany*
}

\begin{abstract}
The harpacticoid copepod Tisbe holothuriae has been cultivated in the Helgoland laboratory for more than 20 years. The effects of density on the larval development and the female productivity were studied by comparing two culture systems: (1) enclosed system, and (2) runningwater system. In both systems, a nutritious mixed diet of Dunaliella tertiolecta, Skeletonema costatum, and granulated Mytilus edulis was offered. Larval mortality, larval development and female productivity are found to be significantly dependent on both the population density and specificity of the culture system. Increasing density causes higher larval mortality, longer larval development time, and a reduction in female productivity. In comparison with the enclosed system, the running-water system shows decisive advantages: larval mortality is about $20 \%$ lower, the rate of larval development is about two days shorter, and there is a very high rate of nauplii production. The sex ratio exhibits high variations, but in general, there is no clear relationship between sex ratio and population density. Nevertheless, when reared in the running-water system, a relatively high percentage of females $(>45 \%)$ was found at lower densities.
\end{abstract}

\section{INTRODUCTION}

With the rapid development of fish and crustacean aquaculture systems, the requirements for living food organisms become more and more urgent. Among the wide spectrum of available food organisms, Copepoda have been proved to be one of the most important food sources, especially for fish fry production (May, 1970; Fujita, 1973, 1977; Rothbard, 1976; Gopalan, 1977; Kinne, 1977). There is also some evidence that Copepoda are of higher nutritional value for fish larvae than nauplii of Artemia salina (Watanabe et al., 1978, 1983; Fukusho et al., 1980; Dabrowski \& Rusiecki, 1983; Kraul et al., 1991a, b). Among copepods, harpacticoids appear to be well-suited as food organisms. Due to their short life-cycle, and the high productivity of females, many species are easily reared in mass cultures (Uhlig, 1981, 1984a, b).

Tisbe holothuriae has been continuously cultivated in our laboratory since 1963. Originally, $T$. holothuriae proved to be a useful component in cultures of certain sessile organisms like folliculinids (ciliates), as well as small invertebrates (hydrozoa etc.), to keep culture dishes clean from various deposits and overgrowing microorganisms like

- Correspondence to G. Uhlig, Zu den Brüchen 3, D-59427 Unna-Billmerich 
bacteria or fungi (Uhlig, 1964, 1965). Mass cultivation of $T$. holothuriae started in 1977. Many experiments have been carried out to study the effects of essential environmental parameters such as temperature, salinity, light and food on growth, reproductivity, and population dynamics (Gaudy \& Guérin, 1977; Schwenzer, 1985). A few references are available concerning the population dynamics of Tisbe (Hoppenheit, 1975, 1976; Gaudy, 1982). There is little information about the effects of density on growth and reproduction, especially in mass culture. Uhlig (1984a), and Schwenzer \& Uhlig (1988) presented some results of the relationship between initial density and nauplii survival. Our recent study demonstrates the importance of density in larval development and female productivity, especially when reared in an enclosed system (Zhang \& Uhlig, 1991). With the present study we tried to determine the immediate effects of density: (1) on larval mortality and generation time; (2) on female fecundity; (3) on nauplii production; and (4) on the sex ratio. In order to clarify secondary effects by deterioration of the medium, all experiments were carried out within two different culture systems: (1) an enclosed system, and (2) a running-water system.

\section{MATERIALS AND METHODS}

Tisbe holothuriae was originally isolated from the swimming pool on Helgoland in 1962 (Uhlig \& Noodt, 1966). It has been mass-cultivated mainly in enclosed systems (for details see Uhlig, 1984a). Organisms used for experiments derived from the stock of mass cultures. The cultures were kept in millipore-filtered and pasteurized $\left(96^{\circ} \mathrm{C}\right)$ seawater of $28 \%$ salinity, $20 \pm 1{ }^{\circ} \mathrm{C}$ temperature, $12 \mathrm{~h}$ light-dark conditions, and an excess of a mixed diet of Dunaliella tertiolecta, Skeletonema costatum and grains of dehydrated mantletissue of Mytilus edulis. In both culture systems, four density levels: 20,60, 180 and 540 nauplii/ $/ \mathrm{cm}^{2}$ were used for larval development experiments, and 3, 9, 40 and $140 \mathrm{~g} / \mathrm{cm}^{2}$ for the experiments on productivity. In the running-water system, additionally, two higher density levels of 1000 and 1500 nauplii $/ \mathrm{cm}^{2}$ were tested. The results were based on three replications for each density. To study female fecundity, four ovigerous females of each culture, i.e. 12 ovigerous females for each density, were selected and reared individually in small bowls $(20 \mathrm{ml})$ and returned to the original bowl after the hatching of nauplii. Fecundity is expressed as the mean number of nauplii hatched from one egg-sac per female.

In the enclosed system we used flat glass bowls $1 \varnothing=11.5 \mathrm{~cm}$, area $\approx 100 \mathrm{~cm}^{2}$, water volume $\approx 400 \mathrm{ml}$ ), the culture medium being totally renewed daily. The running-water system is demonstrated in Figure 1. Twelve $8 \mathrm{~cm}$ plexiglass cylinders were used for cultivation, one end covered with a nylon gauze of $50 \mu \mathrm{m}$. These were suspended by means of styrofoam rings floating on the water surface of a 100-1 tank. Each floating culture was connected with an air pump system. Dunaliella and Skeletonema were added into the 100-1 tank, and the culture medium and distribution of food algae controlled daily. Depending on the amount of food available, 10 percent of the culture medium was sucked off and new algae were added every two or three days. Additionally, grains of Mytilus were put into each floating culture to be sure that there was always a surplus of food. In experiments with females, the culture medium was completely changed every 10 days to avoid deterioration.

In order to get an almost simultaneous development, the nauplii were sieved and only $50-80 \mu \mathrm{m}$ sized nauplii were chosen for experiments. Females were sieved through 


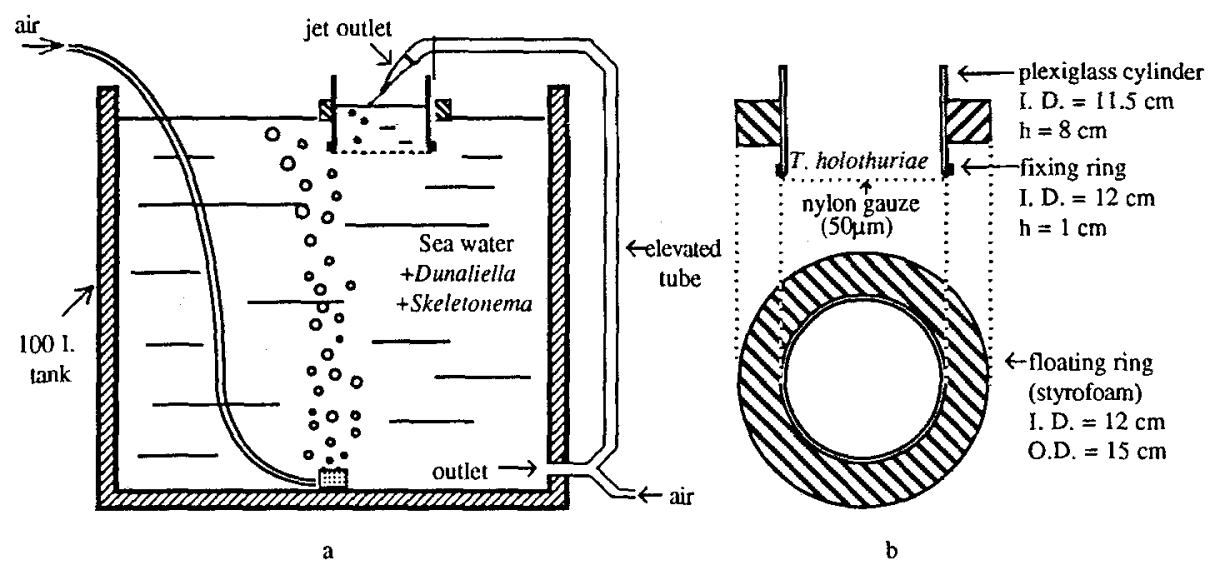

Fig. 1. Diagram of running-water system for cultivation of Tisbe holothuriae; a: side view of whole system; b: side and top view of floating sieve

$200 \mu \mathrm{m}$ gauze as soon as they matured. The daily nauplii production was collected by sieving the females through $125 \mu \mathrm{m}$ gauze, and afterwards concentrating on $50 \mu \mathrm{m}$ gauze for counting. The method of counting was described in Uhlig (1984b). A Macintosh computer was used to process the data; T-test was used for statistical analysis.

\section{RESULTS}

\section{Effects of density during the larval stages}

In order to study the crowding effects on larval mortality and development, the larvae were counted daily at the beginning and near the end, and twice or three times in the middle of the experiment. In both systems, larval mortality significantly increases with increasing density, i.e. within the enclosed culture system from $24 \%, 28 \%, 44 \%$ and $64 \%$ (four density ranges 20 to 60,180 to $540 \mathrm{ind} / \mathrm{cm}^{2}$ were tested), respectively, and $3 \%$, $15 \%, 28 \%, 56 \%, 68 \%$, and $78 \%$ in the running-water system (six ranges tested: 20 to 1500 ind $/ \mathrm{cm}^{2}$, see Fig. 2). Larval mortality in the running-water system is more than 10 percent lower than that in the enclosed system.

The cumulative daily larval mortality was also observed in the running-water system (cf. Fig. 2). It is evident that copepodites react more to varying densities than the nauplii and adults. In the first three days, i.e. during the naupliar phase, there are no significant differences in mortality among all the densities tested. However, the differences become more and more distinct in the days following. Again, after maturity, relatively few changes are observed. On the other hand, high density causes large variations in larval development. At the lowest density $\left(20 \mathrm{ind} / \mathrm{cm}^{2}\right)$, more than $50 \%$ of the larvae became copepodites on the second day, and more than $90 \%$ on the third day. Whereas at the highest density $\left(1500 \mathrm{ind} / \mathrm{cm}^{2}\right)$, the proportion of copepodites was only $10 \%$ on the third day, and it took six days for more than $90 \%$ of the larvae to develop into copepodites. Thus, the development from nauplii to copepodites essentially takes longer at higher densities. Regarding the maturing phase of the females, a similar situation has been 

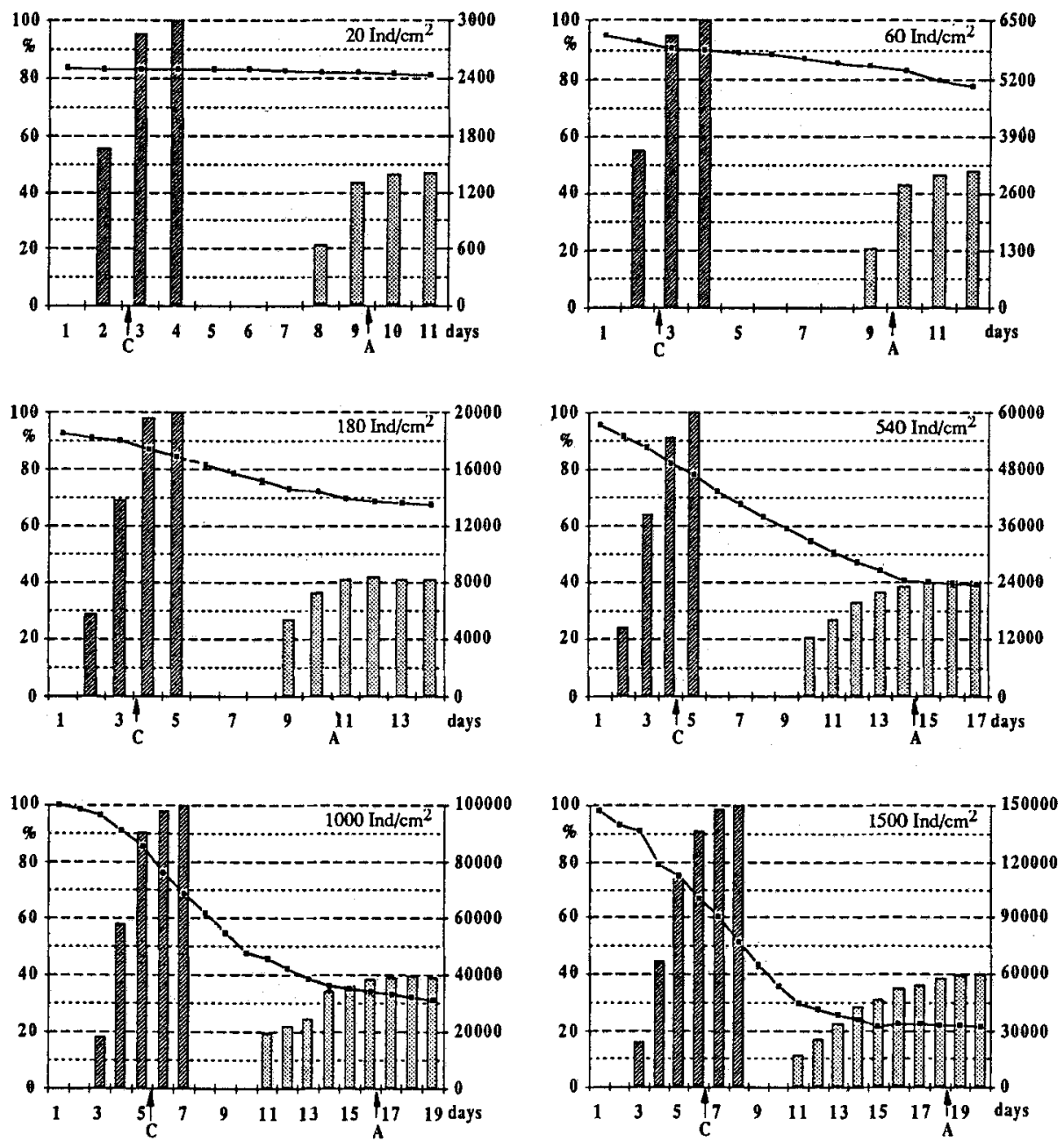

$\rightarrow$ Number of survivors

Percentage of copepodites

Percentage of females

Fig. 2. Survival curves of $T$. holothuriae during their development from larvae to adult, cultivated in six increasing density levels in a running-water system. The arrows indicate (C) the appearance of copepodite stages (more than $90 \%$ nauplii developed to copepodites) and (A) adult stage (all larvae have matured and the percentage of females keeps relatively steady)

observed. At lower densities $\left(20-180\right.$ ind $\left./ \mathrm{cm}^{2}\right)$ about $20-40 \%$ mature females were observed on the eighth day, and from the ninth day the percentage of females remained relatively steady. At higher densities $\left(540-1500 \mathrm{ind} / \mathrm{cm}^{2}\right)$, however, the percentage increased continuously from the 11 th to the 18 th day from $10-40 \%$ (Fig. 2).

It is also obvious that the larval development from nauplii to adults is dependent not only on culture density, but also on the culture system. In the enclosed system the time of development from nauplii to adults varies from 11 to 16 days, with increasing density. 


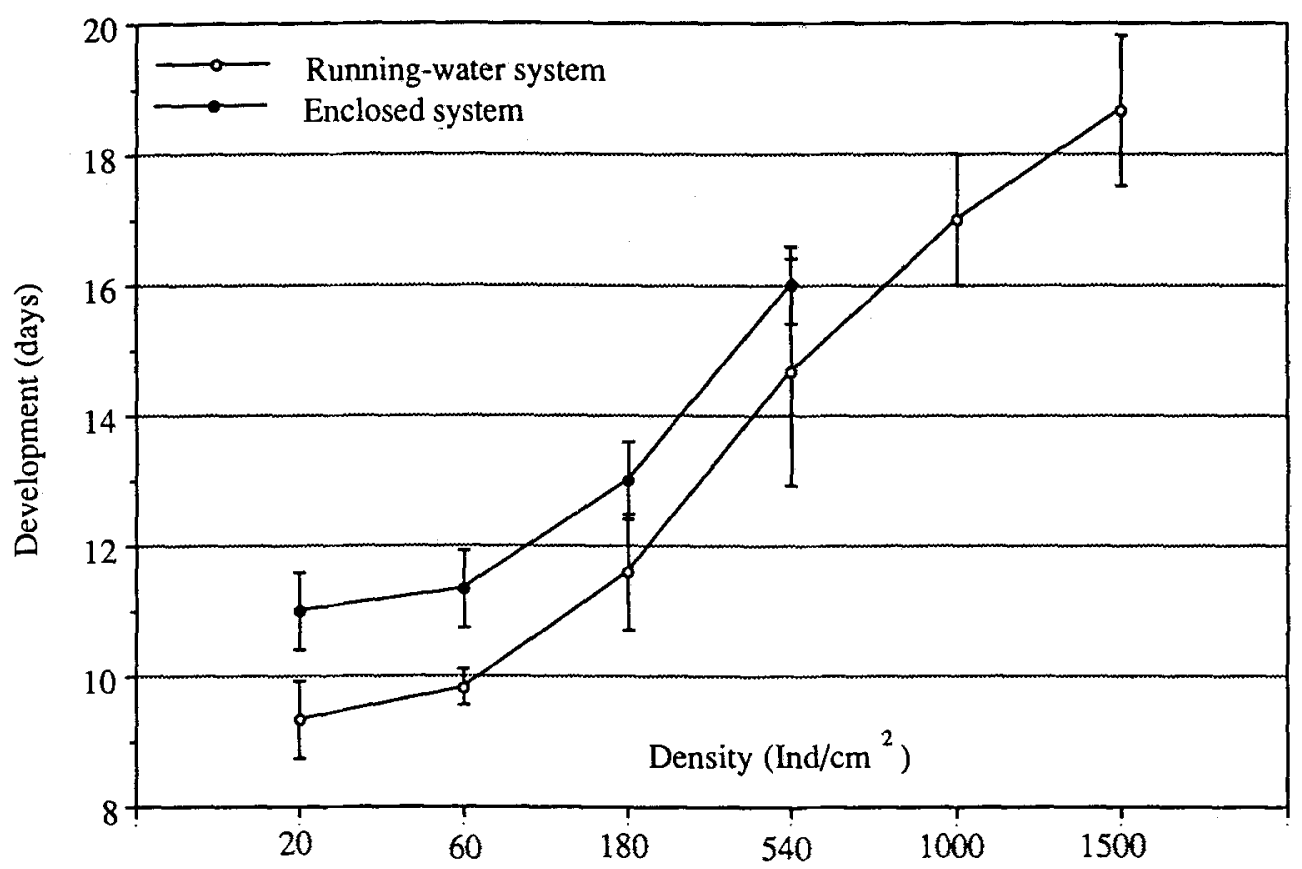

Fig. 3. Larval development time ( \pm s.d.), from nauplii to adult, of $T$. holothuriae reared at different densities with two different culture systems

However, nauplii reared in the running-water system develop faster than those in the enclosed system.

After maturity female fecundity was examined in the running-water system. It was found that the density in larval stages also plays an important role in the earliest female fecundity (Fig. 4). Female fecundity decreases with increasing density.

The sex ratio is found to fluctuate irregularly among all the copepods, at different densities within the enclosed system. The percentage of females varies between $35 \%$ to $46 \%$, with $40 \%$ on average. In the running-water system, however, with increasing density there seems to be a trend towards a slight decline in the percentage of females, although the differences are not statistically significant, due to a relatively high individual variability.

\section{Effects of density during the female breeding phase}

Female mortality was determined in both culture systems. In the enclosed system, the females were counted daily at the beginning and at the end of the experiment, within a 19-day period. Afterwards, only very low yields of nauplii were registered at all density levels. The results display significant differences of female mortality within the density levels tested ( $p<0.01$, see Fig. 5). In the running-water system, the number of females were counted every fourth day within the 33-day period in order to estimate the variation trend in female mortality during the breeding phase. As shown in Figure 6, within the first 10 days female mortality was very low in all cultures, but later increased more 


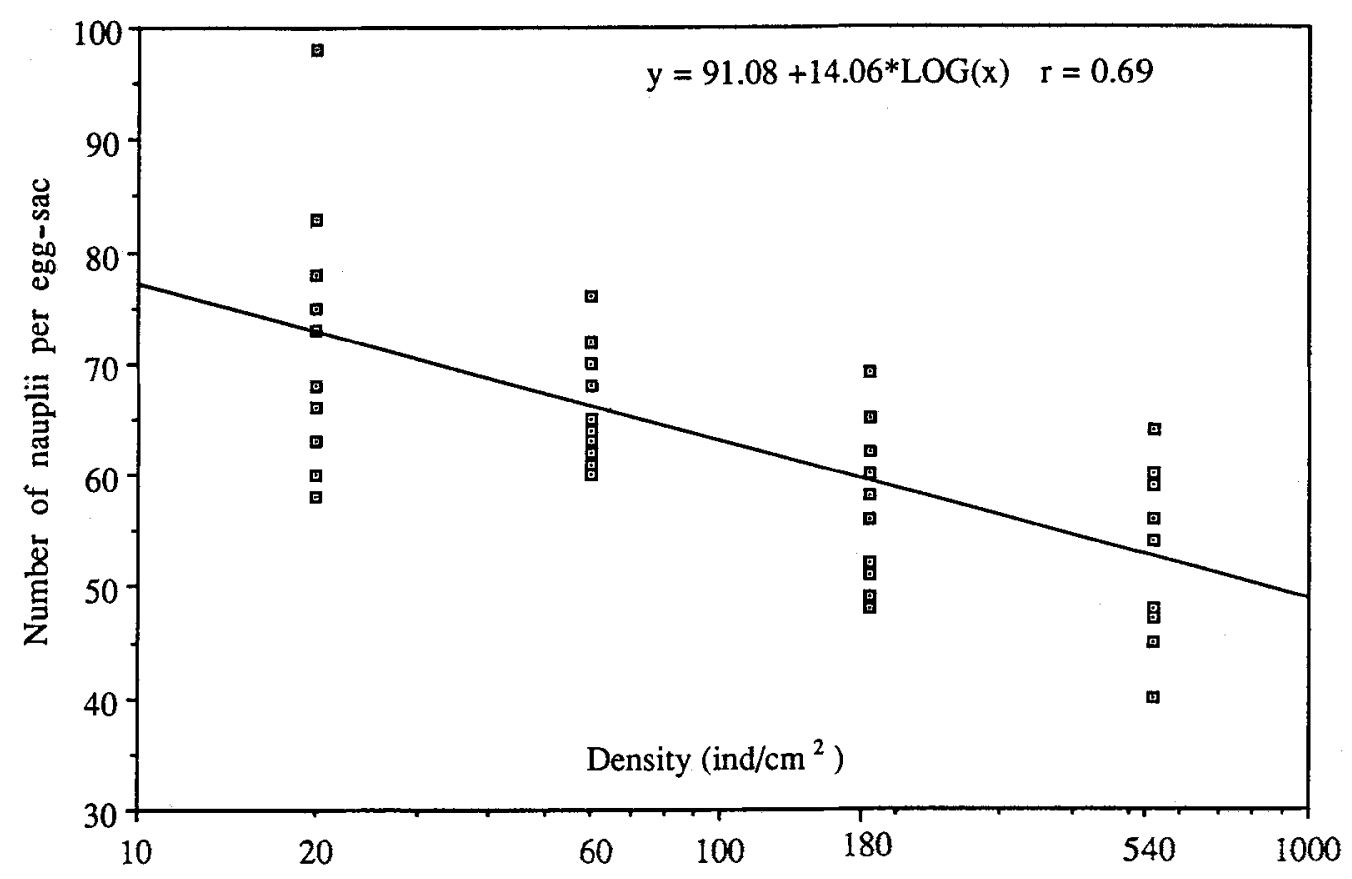

Fig. 4. Relationship between fecundity and larval density of $T$. holothuriae in the running-water system

rapidly, at lower than at higher individual density. In combination with the data on nauplii yield, it is quite obvious that females reared in a lower density show much higher productivity within relatively shorter breeding phases.

The mean number of nauplii production per female per day, calculated by dividing the daily nauplii yield by the surviving number of females, is used to compare female productivity at different densities. In both culture systems, females offer the highest productivity at the lowest density level $\left(3 q / \mathrm{cm}^{2}, \mathrm{Fig} .7\right)$. Production in the running-water system is by far higher than presented in recent literature. A very high rate of nauplii production (on average more than 25 nauplii/ $q /$ day) was sustained for about 18 days and even more than 40 nauplii/ $9 /$ day was achieved from the 8 th to the 15 th day at low densities of 3 and $9 \mathrm{q} / \mathrm{cm}^{2}$. In addition, as far as daily nauplii production in total is considered, the yield increased with increasing density, but decreased at the highest density $(6400,16000,54000$ and 45000 nauplii/day on average, respectively). The highest daily nauplii yield was obtained at the density of $40 \% / \mathrm{cm}^{2}$.

Female fecundity, as well as the percentage of ovigerous females, was susceptible to density on the 10th day of the experiment in the enclosed system. High density levels reduce the number of nauplii hatched per egg-sac and inhibit the female from producing the egg-sac. At the lowest density $\left(3 q / \mathrm{cm}^{2}\right)$, on average 72 nauplii hatched from one egg-sac $(\mathrm{N}=12)$; however, at the highest density $\left(140 \% / \mathrm{cm}^{2}\right)$ only 36 nauplii/egg-sac $(\mathrm{N}$ $=12$ ). The percentage of ovigerous females decreased from $78 \%$ to $45 \%$ with increased density (Fig. 8). Both parameters were also examined at intervals of three days in the 


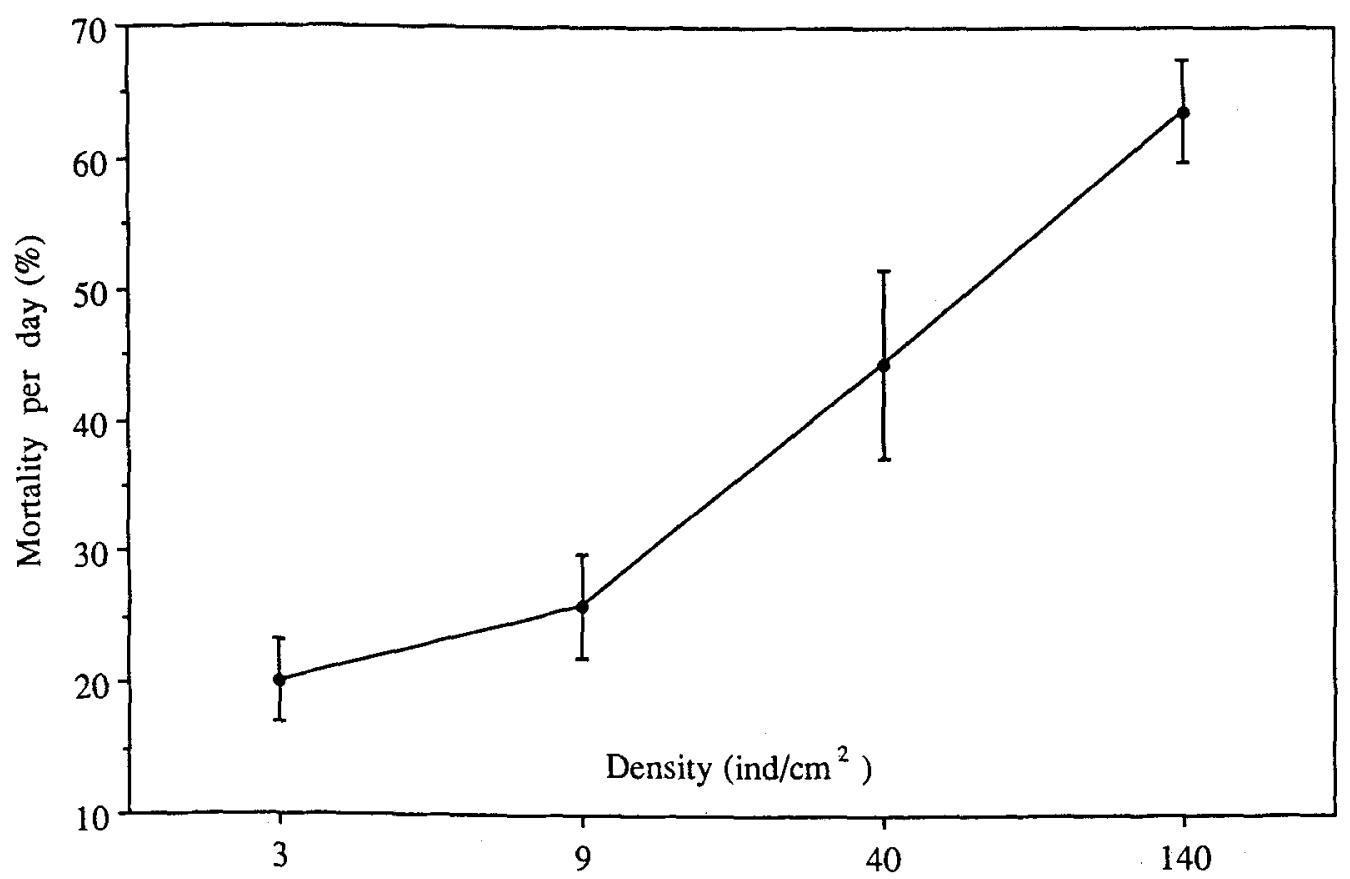

Fig. 5. Female mortality of $T$. holothuriae at increasing density levels in the enclosed system

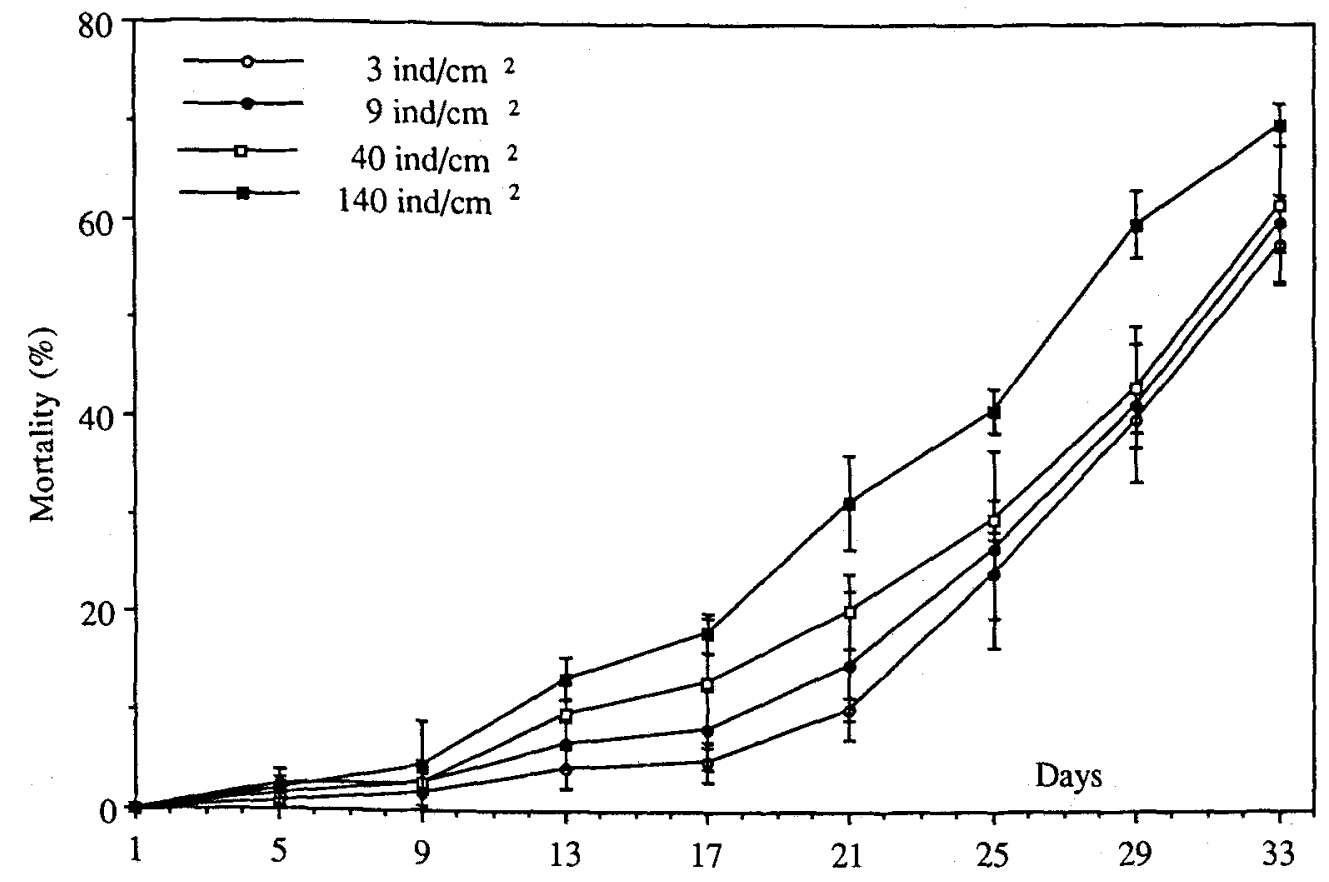

Fig. 6. Cumulative mortality of females of $T$. holothuriae, reared at different densities in the runningwater system 

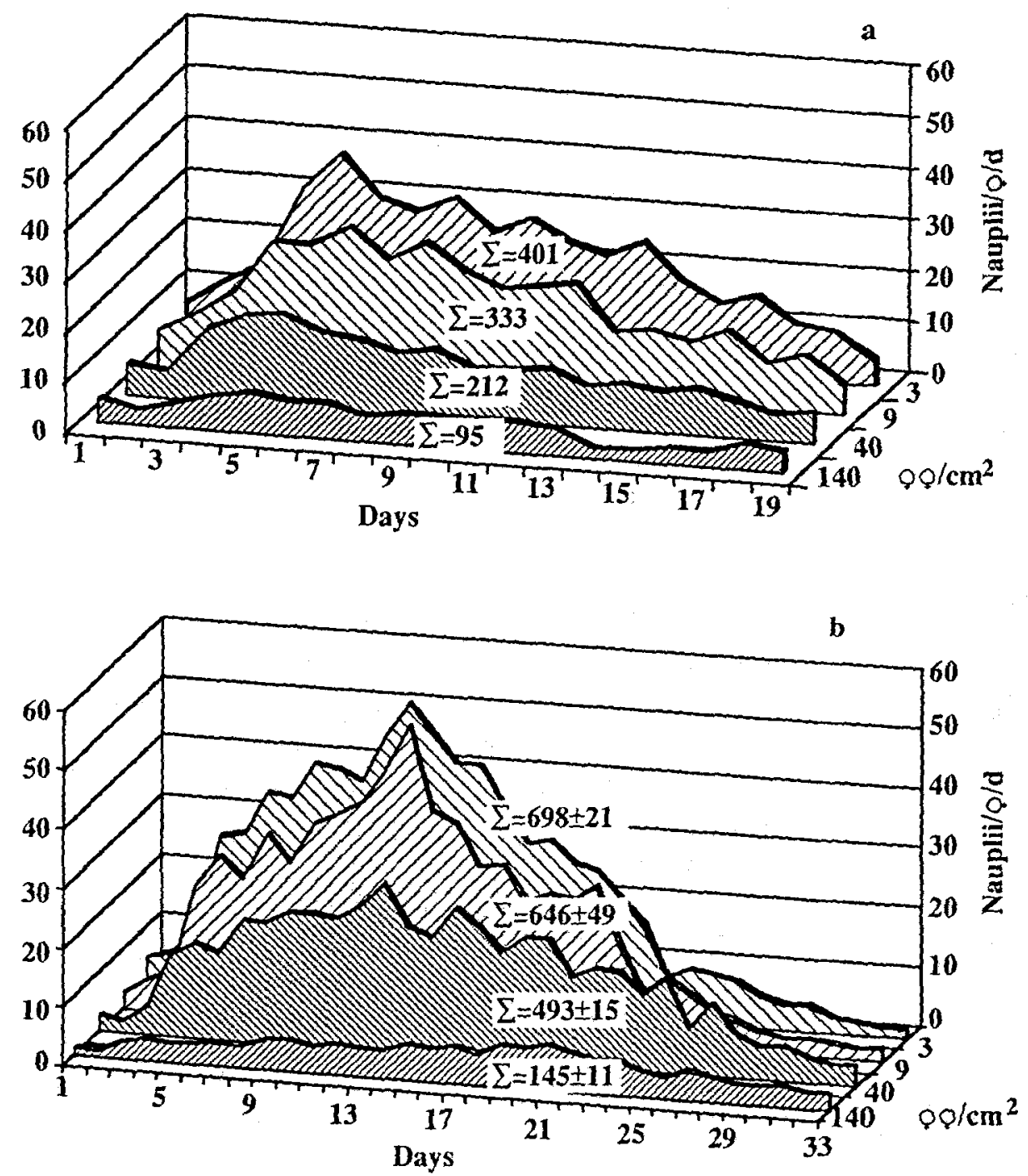

Fig. 7. Female productivity of $T$. bolothuriae cultured at different densities in a) the enclosed system; b) the running-water system

running-water system to estimate their variation trend during their breeding phase. On average, there is a marked peak at lower densities, with more than 70 nauplii and over $90 \%$ of ovigerous females; but there is no peak at the highest density where fecundity was about 40 nauplii/egg-sac, and the percentage of ovigerous females ranges between $40 \%$ and $30 \%$ (Figs 9 and 10 ). 


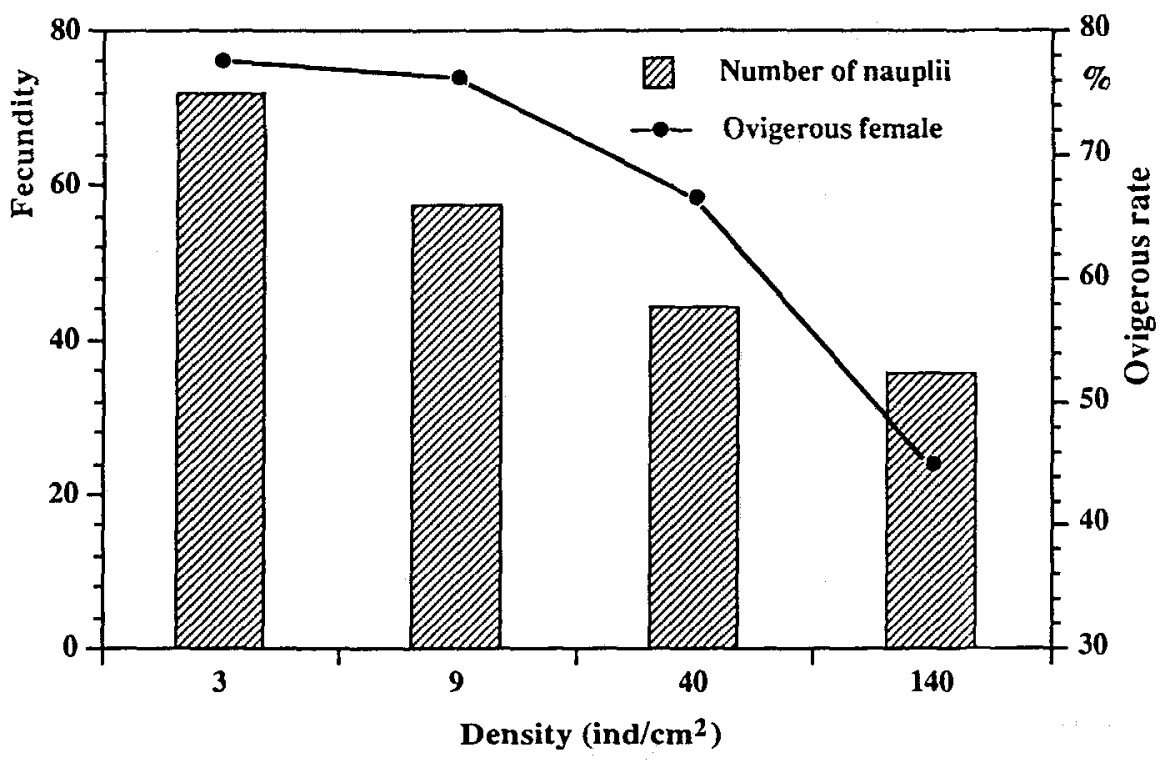

Fig. 8. Fecundity and ovigerous rate of 10-day old females of $T$. holothuriae reared at different densities in the enclosed system

\section{DISCUSSION}

As demonstrated by Uhlig (1981), the mass culture of Tisbe is essentially related to the available substrate area, but less to the available water volume. Therefore, in our experiments, the density refers to the number of individuals per unit area. On the other hand, in order to make the data comparable, the experiments in both the enclosed and the running-water systems were carried out under exactly the same conditions, including temperature, salinity, light and food, and culture containers.

The results presented above indicate that the running-water system gives much better results than the enclosed system, even better than a semi-open floating system (as described by Uhlig, 1984a, b). In comparison, the running-water system as used for the experiments has the advantage of delivering optimal water conditions. Using an air pump, the water from the large tank can be elevated and injected into each floating culture. There is therefore a continuous exchange between the culture medium within the experimental culture and the large water tank. Although the total system exhibits in fact an enclosed system, the volume of this tank is large enough to avoid the considerable deterioration of the medium. In our previous experiments (Zhang \& Uhlig, 1990), especially at high density levels, strong $\mathrm{pH}$ fluctuations of the culture medium have been registered in the small enclosed culture systems just before, and also after, the daily water exchange; no $\mathrm{pH}$ changes were found in the running-water system. Moreover, by means of the jet water outlets, sufficient water exchange and turbulence within the cultures were guaranteed, so as to prevent animals from gathering (perhaps by their phototactical behaviour) which could result in a local lack of oxygen and food. Furthermore, with the running-water system a mixed diet can be used, whereas in a semi-open system only. 


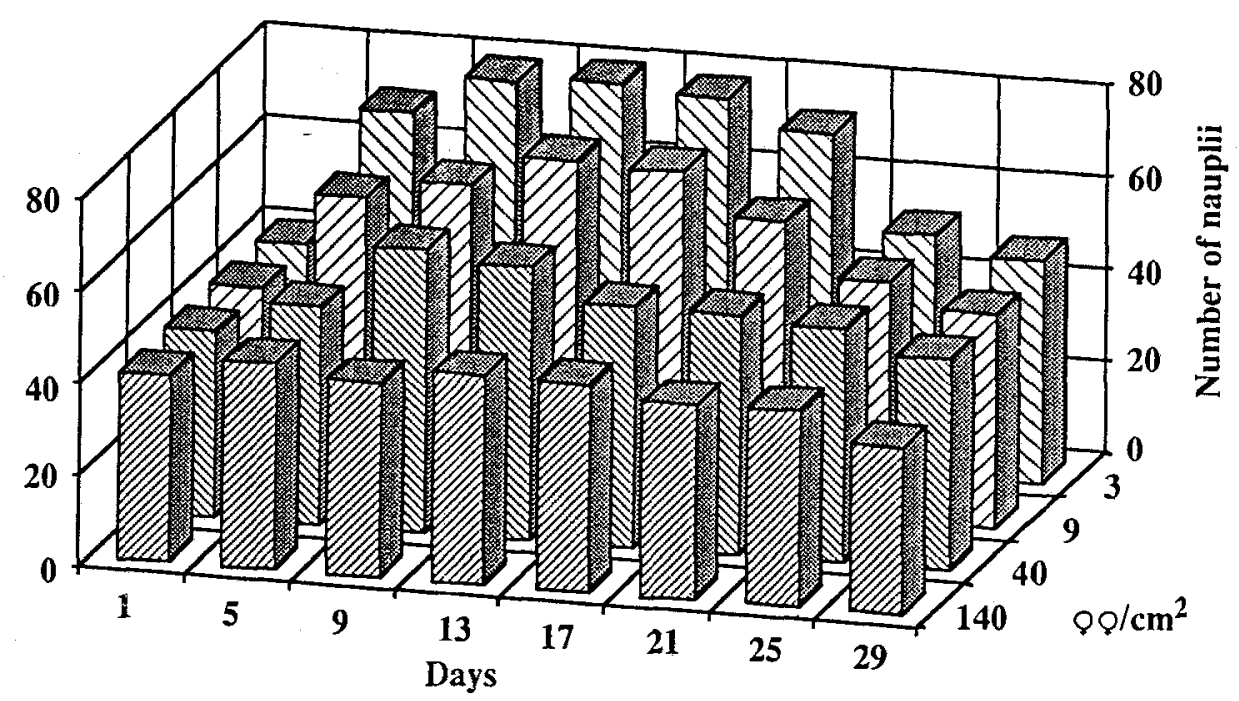

Fig. 9. Female fecundity of $T$, holothuriae reared at different densities in the running-water system during their breeding phase

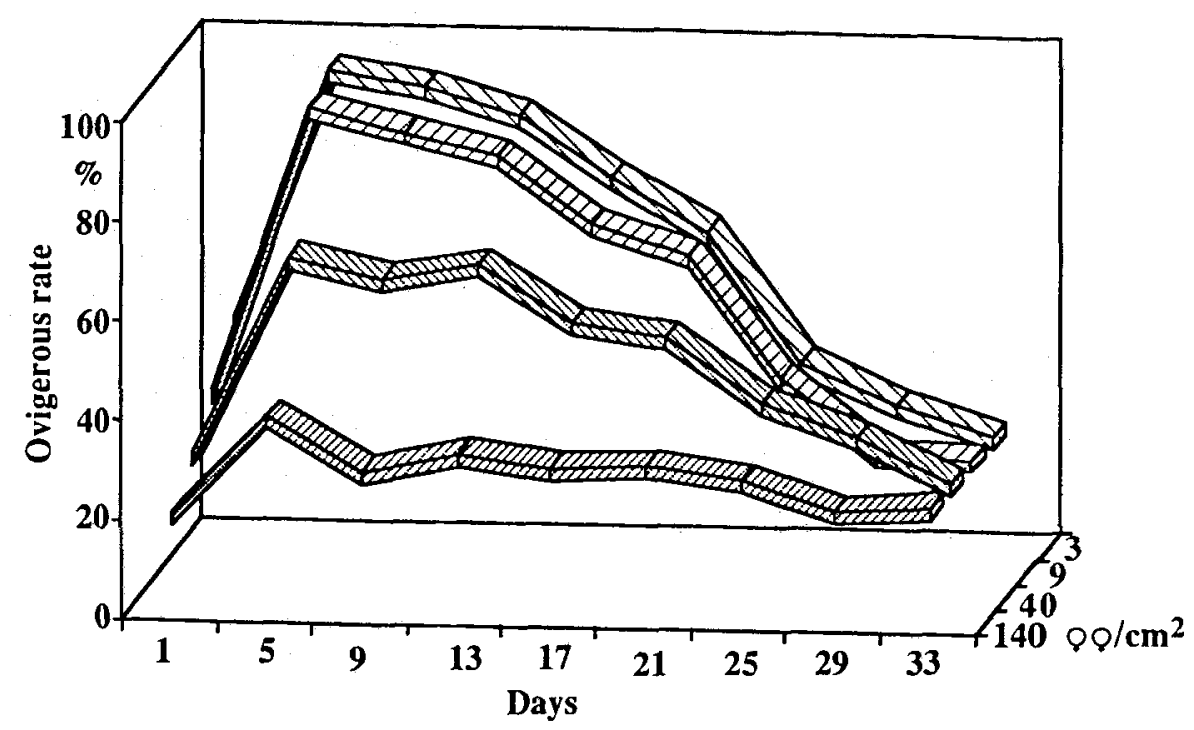

Fig. 10. Female ovigerous rate of $T$. holothuria reared at different densities in the running-water system during their breeding phase

granulated food like Mytilus edulis can be offered as the nutritional source. From our experience (see also Schwenzer, 1985) a mixed diet is of higher nutritional value and always gives better rearing results.

Even when shown to be an excellent design for experimental studies, how this method could be transformed and modified for applicability on much larger scales of 
nauplii production has to be proved on a more biotechnological platform. In this instance it should be possible to offer high, and stable numbers of various stages of Tisbe in fish fry hatch tanks as a food source for young fish larvae. Taking into account a density of $40 \% /$ $\mathrm{cm}^{2}$, a daily yield of more than 83000 nauplii/day could be sustained for over 16 days per floating culture of $100 \mathrm{~cm}^{2}$. Therefore, an extrapolation on twelve such floating sieves will provide an approximate density of 10 nauplii/ml in the total volume of a 100-1 tank. This density is certainly higher than that recommended for rearing various marine fish fry on nauplii (Rosenthal \& Hempel, 1970; Houde, 1978).

It is evident that, with an increasing population density, the larval development is affected in two ways: (1) increase of mortality, and (2) prolongation of development time from nauplii to adults. This is in accordance with previous studies (Uhlig, 1984a). Nevertheless, the different experimental conditions and methods used do not allow a more precise comparison. According to Fava \& Ringoli (1977) the larval survival rate of Tisbe clodiensis was lowered by crowding. The extensive studies of Hoppenheit (1975, 1976) on exploited populations indicated that naupliar mortality was lowest at highest exploitation rates (i.e. at a very low population density). He proposed some factors called "imprinting" to explain the mechanism that enables animals to perceive and respond to different crowding levels. Fava \& Crotti (1979) suggested a complex chemical compound might be produced by the animals as a reaction to crowding. However, the crowding effects are still obvious and verifiable when cultures of different densities are reared in the running-water system, where all of them are exposed to identical conditions even within the same culture medium. Chemical compounds, if they exist, (1) would be extremely diluted in the large tank, and (2) would equally influence all of the cultures involved. From this point of view, there is more agreement with the finding of Brand (1985) that the direct close encounter may change the behaviour of the animals, and even their development.

The regulation of the sex ratio still remains a complex problem. Different authors associate it with many varied factors. According to Fava \& Ringoli (1977) the sex ratio, i.e. the female percentage, was affected by crowding; Hoppenheit (1976) found the opposite results in exploited populations. He proposed that the sex ratio was influenced by the removal rate or the average population density between exploitation: a surplus of males was observed at $90 \%$ removal rate, while a higher percentage of females was found at the rate of $10 \%$. Unfortunately, we did not get satisfactory results in our experiments. Nevertheless, in the running-water system relatively high female percentages occurred at low densities. Conversely, a very low percentage of females was found in the highly populated cultures.

Similar results were also presented by Uhlig (1984a). It seems that high density depresses the proportion of females. But it is still unknown, how density might affect the sex ratio. In Tigriopus japonicus, Egami (1951) found that the modification of sex ratio occurred in the fifth nauplii stage, but his results did not take into account an eventual differential mortality of one of the two sexes during larval development. Further studies on the selective mortality of specific larval stages and sexes would be suggested, to understand how the sex ratio is regulated in Tisbe.

The results presented above reveal the marked effect crowding has on female productivity. Female fecundity is affected not only by the density of females during their breeding phase, but also by the density of larvae during the larval stages. Fava \& Crotti 
(1979) found the crowding of females during mating time caused a decreasing number of nauplii hatched from the first egg-sac. This is in close agreement with our results. Moreover, we find that this effect of crowding can be remedied when the females are removed to better conditions (Zhang \& Uhlig, 1991). During their breeding phase the fecundity of females varies according to different densities. As demonstrated by our experiments, the low densities give rise to a relatively high fecundity, but also a shorter breeding phase. On the other hand, the density affects productivity by reducing the percentage of ovigerous females. The low percentage of ovigerous females in high density cultures may be explained by extended intervals between the release of the successive egg-sacs. Walker (1979) got similar results in Amphiascoides. This interpretation is also supported by Gaudy (1982): that in exploited populations the ovigerous rate is higher with more frequent harvesting.

It is shown that population density is of great importance in mass cultivation of Tisbe holothuriae. From the point of daily nauplii yield, this is highest when females are kept at a density of $40 \mathrm{q} / \mathrm{cm}^{2}$. To replace the exhausted and dying females, it is necessary to keep some supplemental cultures. In this context a density of 180 nauplii/ $\mathrm{cm}^{2}$ is suggested, to provide a sufficient quantity of females for generation succession. At this density, the larval mortality is about $30 \%$ and after growing-up, a percentage of about $40 \%$ females will be expected. Thus, about 11 days later, more than $40 \% / \mathrm{cm}^{2}$ will be harvested, which happens to be also the best density for nauplii production.

Acknowledgements. This research was carried out within the scope of the German-Chinese Cooperation Program, supported by the German Ministry of Research and Technology. The authors would like to thank G. Sahling (Biologische Anstalt Helgoland) for his helpful suggestions in the process of data analyses.

\section{LITERATURE CITED}

Brand, G. W., 1985. Effect of crowding on larval viability in Tisbe holothuriae. - Mar. Biol. 88, 67-72.

Dabrowski, K. \& Rusiecki, M., 1983. Content of total and free amino acids in zooplanktonic food of fish larvae. - Aquaculture 30, 31-42.

Egami, N., 1951. A note on the sex differentiation of the marine copepod Tigriopus japonicus. Annotnes zool. jap. 24, 131-136.

Fava, G. \& Crotti, E., 1979. Effect of crowding on nauplii production during mating time in Tisbe clodiensis and T. holothuriae (Copepoda, Harpacticoida). - Helgoländer wiss. Meeresunters. 32, $466-475$.

Fava, G. \& Ringoli, C., 1977. Effect of the larval density on survival in the harpacticoid copepod Tisbe clodiensis. - Rapp, P.-v. Réun. Commn int. Explor. scient. Méditerr. 24 (4), 135-136.

Fujita, S., 1973. Importance of zooplankton mass culture in producing marine fish seed for fish farming. - Bull. Plankt. Soc. Japan 20, 49-53.

Fujita, S., 1977. The present status and problems of marine fish breeding techniques in Japan. Proc. 5th Japan-Soviet Joint Symposium on Aquaculture (Tokyo and Sapporo). Ed. by S. Motoda. Tokai Univ., Tokyo, 327-338.

Fukusho, K., Arakawa, T. \& Watanabe, T., 1980. Food value of a copepod, Tigriopus japonicus, cultured with w-yeast for larvae and juveniles of mud dab Limanda yokohamae. - Bull. Jap. Soc. scient. Fish. 46, 499-503.

Gaudy, R, 1982. Population dynamics of Tisbe holothuriae (Copepoda:Harpacticoida) in exploited mass cultures. - Neth. J. Sea Res. 16, 208-216.

Gaudy, R. \& Guérin, J. P., 1977. Dynamique des populations de Tisbe holothuriae (Crustacea:Copepoda) en élevage sur trois régimes artificiels différents. - Mar. Biol. 39, 137-145.

Gopalan, U. K., 1977. Experimental mass culture of a harpacticoid copepod Nitocra spinipes Boek. 
In: Proceedings of the symposium on warm-water zooplankton. National Institute of Oceanography, 558-562.

Hoppenheit, M., 1975. Zur Dynamik exploitierter Populationen von Tisbe holothuriae (Copepoda, Harpacticoida). II. Populationsdichte, Alterszusammensetzung, Wachstum und Ausbeute. Helgoländer wiss. Meeresunters. 27, 377-395.

Hoppenheit, M., 1976. Zur Dynamik exploitierter Populationen von Tisbe holothuriae (Copepoda, Harpacticoida). III. Reproduktion, Geschlechtsverhältnis, Entwicklungsdauer und Überlebenszeit. - Helgoländer wiss. Meeresunters. 28, 109-137.

Houde, E. D., 1978. Critical food concentrations for larvae of three species of subtropical marine fishes. - Bull. mar. Sci. Gulf Caribb. 28, 395-411.

Kinne, O., 1977. Copepoda. In: Marine Ecology. Ed. by O. Kinne. Wiley-Interscience, London, 3 (2), $761-797$.

Kraul, S., Ako, H., Brittain, K., Ogasawara, A., Cantrell, R. \& Nagao, T. 1991a. Comparison of copepods and enriched Artemia as feeds for larval mahimahi Coryphaena hippurus. - Spec. Publ. Eur. Aquacult. Soc. 15, 45-47.

Kraul, S., Ako, H., Brittain, K. \& Ogasawara, A., 1991b. Evaluation of live feeds for larval and postlarval mahimahi Coryphaena hippurus. - J. World Aquaculture Soc. (in press).

May, R. C., 1970. Feeding larval marine fishes in the laboratory: a review. - Calif. coop. ocean. Fish. Invest. Rep. 14, 76-83.

Rosenthal, H. \& Hempel, G., 1970. Experimental studies in feeding and food requirements of herring larvae (Clupea harengus L.). - In: Marine food chains. Ed. by J. H. Steele. Oliver \& Boyd, Edinburgh, 344-364.

Rothbard, S., 1976. Experiments in mass culture of marine copepoda Tigriopus japonicus (Mori) on a bed of crushed sea weed Ulva petrusa (Kjelman). - Bamidgeh 4, 80-105.

Schwenzer, D., 1985. Untersuchungen zur Produktionsbiologie von Tisbe holothuriae (Copepoda, Harpacticoida) bei unterschiedlichen Temperatur-, Salinitäts- und Nahrungsbedingungen. Diss., F. U. Berlin, 197 pp.

Schwenzer, D. \& Uhlig, G., 1988. Massenzüchtung von Copepodenlarven als Lebendfutter. - Jber. Biol: Anst. Helgoland 1988, 58-59.

Uhlig, G., 1964. Kulturexperimente an dem harpacticoiden Tisbe n. sp. - Jber. Biol. Anst. Helgoland 1964, Ca20.

Uhlig, G., 1965. Die mehrgliedrige Kultur litoraler Follikuliniden. - Helgoländer wiss. Meeresunters. $12,52-60$.

Uhlig, G., 1981. Microfaunal food organisms for mariculture. - Spec. Pubi. Europ. Maricult. Soc. 6, 93-115.

Uhlig, G., 1984a. Massenproduktion von Lebendfutter für Marikultur-Systeme. - Jber. Biol. Anst. Helgoland 1984, 80-83.

Uhlig, G., 1984b. Progress in mass cultivation of harpacticoid copepods for mariculture purposes. Spec. Publ. Europ. Soc. 8, 261-273.

Uhlig, G. \& Noodt, W., 1966. Tisbe helgolandica n. sp. aus dem Seewasser-Freibad Helgoland. Kieler Meeresforsch. 22, 133-137.

Walker, I., 1979. Mechanisms of density-dependent population regulation in the marine copepod Amphiascoides sp. (Harpacticoida). - Mar. Ecol. Prog. Ser. 1, 209-221.

Watanabe, T., Arakawa, T., Kitajima, C., Fukusho, K. \& Fujita, S., 1978. Nutritional quality of living feed from the viewpoint of essential fatty acids for fish, - Bull. Jap. Soc. scient. Fish. 44, 1223-1227.

Watanabe, T., Kitajima, C. \& Fujita, S., 1983. Nutritional values of live organisms used in Japan for mass propagation of fish: a review. - Aquaculture 34, 115-143.

Zhang, Q. \& Uhlig, G., 1990. Einfluß der Populationsdichte auf die Larvalentwicklung von Tisbe holothuriae unter Laborbedingungen. - Jber. Biol. Anst. Helgoland 1990, 57

Zhang, Q. \& Uhlig, G., 1991. Progress in mass cultivation of harpacticoid copepods of the genus Tisbe. - Spec. Publ. Europ. Aquacult. Soc. 15, 98-100. 